Lymphangiography has been used previously to show the extent of retroperitoneal tuberculous lymphadenitis (Babeau \& Fournier, 1965). The foamy appearance shown in their cases was similar to that in Case 2 and to that in another case of retro-peritoneal tuberculous lymphadenitis without abscess formation seen at Westminster Hospital.

Lymphangiography was found invaluable in Case 2 above, both in confirming the origin of the infection and in assessing progress to treatment. The lipiodol is cleared sufficiently slowly from the nodes, which are otherwise difficult to assess, to be useful in monitoring the response to treatment for up to a year. If the lipiodol is cleared too soon, the endolymphatic injection can be repeated.

The single most valuable study in the diagnosis of retroperitoneal tuberculosis was said by Mitty \& Faegenburg (1964) to be intravenous urogoraphy, but although this investigation is still of value, perhaps pride of place should now be given to lymphangiography.

Although experience is limited at present, the 'foamy' radiological appearances of the nodes seem indistinguishable from those in various reticuloses, so bacteriological or histological confirmation of tuberculosis is advisable.

\section{Acknowledgments}

We are grateful to $\mathrm{Mr} \mathrm{T}$. J. Mott for performing the lymphangiography, and Dr W. F. White for interpreting the films. We wish to thank Mr J. W. M. Leslie and Mr E. S. Lee for allowing us to report their cases.

\section{References}

AIRD, I. (1957) A Companion in Surgical Studies, 2nd edn, p. 1091. Livingstone, Edinburgh.

Babeau, P. \& Fournier, A. (1965) Clinical findings in lipiodol lymphography of various types of tuberculous lymphadenopathy. J. belg. Radiol. 48, 332.

BAER, W.S., BenNetT, G.E. \& NACHLAS, I.M. (1923) Nonspinal psoas abscess. J. Bone Jt Surg. 5A, 590.

BERRY, J.N. (1961) Extrapulmonary tuberculosis. J. Indian med. Ass. 37, 436.

BinNs, J.A. (1966) A rare case of psoas abscess. Brit. J. clin. Pract. 20, 325.

KINMONTH, J.B. (1954) Lymphangiography in clinical surgery and particularly in the treatment of lymphoedema. Ann. Roy. Coll. Surg. 15, 300.

LAM, S.F. \& Hodgson, A.R. (1966) Non-pyogenic psoas abscess. J. Bone Jt Surg. 48A, 868.

MerCer, W. \& DUTHIE, R.B. (1964) Orthopaedic Surgery, 6th edn, p. 343. Williams \& Wilkins, Baltimore.

MitTy. H.A. \& Faegenburg, D. (1964) Retroperitoneal tuberculous lymphadenitis. Amer. J. Roentgenol. 92, 355.

Mynter, H. (1881). Acute psoitis. Buffalo med. Surg. J. 21, 202.

Rogers, M.H. (1911) Psoas abscess from lumbar retroperitoneal glands. Amer. J. Orth. Surg. 9, 232.

Schless, J.M. \& WIER, J.A. (1957) The current status and the treatment of lymphatic tuberculosis. Amer. Rev. Tubercl. 76, 811.

TORDOIR, B.M. (1951) Spasm of and abscess formation in the psoas muscle caused by renal calculus. J. Urol. 66, 638.

ZADEK, I. (1950) Acute non-tuberculous psoas abscess: clinical entity: a report of 7 cases. J. Bone Jt Surg. 32A, 433.

\title{
Massive oedema and ascites during treatment with anti-depressant drugs
}

\author{
James Anthony Child* \\ M.B., M.R.C.P. \\ Medical Unit, Central Middlesex Hospital, London, N.W.10
}

THE OCCASIONAL occurrence of dramatic side-effects in patients taking anti-depressant drugs, particularly the monoamine oxidase inhibitors, as well as the interaction of these with other drugs and with foodstuffs, have been the subject of much interest and concern. Although oedema of the ankles has been noted by several workers in patients on isocarboxazid ('Marplan') (Azima et al., 1959; Griffith, 1960; Mock, Panero \& Robinson, 1961) on amitriptyline ('Tryptizol') (Weiss \& Pressman, 1961) and also where combined anti-depressant drug therapy has been employed (Gander, 1965), the develop-

* Present address: St Bartholomew's Hospital, London, E.C.1. ment of massive oedema would appear to be unrecorded. For this reason the following case is reported.

\section{Case report}

Mrs A.G., a housewife aged 64, was attending the Psychiatric Out Patient Department because of symptoms of anxiety and depression. On 7 March 1967 she was started on diazepam ('Valium') and protriptyline ('Concordin'), following which there was minimal improvement and there were no apparent side-effects. On 31 August 1967 her drug regime was changed to isocarboxazid $10 \mathrm{mg}$ t.d.s., amitriptyline $25 \mathrm{mg}$ t.d.s. and diazepam $20 \mathrm{mg}$ nocte. 
About 4 weeks after this she became aware of increasing swelling of the legs and, subsequently, of the arms and abdomen. She had gained $42 \mathrm{lb}$ $(18.9 \mathrm{~kg})$ in weight up to the time of admission, on 14 November 1967.

On examination: she exhibited generalized pitting oedema, including face, arms and trunk, with gross, painful oedema of the legs. Ascites was detectable. There were no other abnormalities; in particular, the neck veins were not raised and there was no evidence of heart disease. Blood pressure was $130 / 80 \mathrm{mmHg}$.

Investigations: $\mathrm{Hb} .13 .4 \mathrm{~g} / 100 \mathrm{ml}$; PCV $36 \%$; WBC $3400 / \mathrm{mm}^{3}$; platelets, normal; ESR $15 \mathrm{~mm} / \mathrm{hr}$; MSU, normal; 24-hr urine for protein, nil; electrolytes, normal; blood urea, $35 \mathrm{mg} / 100 \mathrm{ml}$; creatinine clearance, $74 \mathrm{ml} / \mathrm{min}$; liver function tests, normal; plasma proteins and electrophoresis, normal; ECG, normal. Chest X-ray, compared with 9 months previously, when the X-ray had been normal, showed minimal cardiac enlargement and fullness of the pulmonary vasculature.

\section{Progress}

She was taken off all the drugs and given diuretics, following which the oedema and ascites subsided satisfactorily and the chest X-ray returned to normal. Subsequently, diuretics were withdrawn and there was no recurrence of the oedema. It was not considered justified to see whether the oedema recurred if the drugs were re-introduced. However, intradermal testing with solutions of the drugs in question revealed a striking sensitivity to isocarboxazid, a weal developing rapidly after injection, there being marked residual local oedema. No adverse skin reactions to the preparation of isocarboxazid were noted in control subjects. She remains well, without drugs, and has been discharged from the Psychiatric Out Patient Clinic.

\section{Discussion}

A case of massive generalized oedema in a patient taking the monoamine oxidase inhibitor isocarbox- azid, together with amitriptyline and diazepam is reported. In the absence of any concurrent disease to account for this and the recovery following withdrawal of the drugs and a short course of diuretics, it is concluded that this represented a side-effect of the drug regimen. It is known that the iminodibenzyl derivatives, such as amitriptyline, may potentiate the monoamine oxidase inhibitors following overdose and even in therapeutic doses, leading to serious reactions, including hyperpyrexia, convulsions and coma (Jarecki, 1963; Sjöqvist, 1965). The mechanism by which such potentiation could lead to fluid retention would appear to be obscure and the skin test in this case suggests rather that the oedema may have occurred as a sensitivity reaction to isocarboxazid.

\section{Acknowledgments}

I am grateful to Dr J. P. Knowles for his permission to report this case and I am also indebted to Roche Products Limited for their help, in particular in the production of a preparation of isocarboxazid suitable for intradermal testing. Professor W. Feldberg, of the Institute of National Medical Research, Mill Hill, kindly gave pharmacological advice.

\section{References}

Azima, H., Durost, H., Arthurs, D. \& Silver, A. (1959) The effect of R0-5-0831/1 ('Marplan') in depressive states. Amer. J. Psychiat. 116, 453.

GANDER, D.R. (1965) Treatment of depressive illnesses with combined antidepressants. Lancet, ii, 107.

GrifFITH, G.C. (1960) The importance of the monoamine oxidase inhibitors in cardiovascular disease. Amer. $J$. Cardiol. 6, 1103.

JARECKI, H.G. (1963) Combined amitriptyline and phenelzine poisoning. Amer. J. Psychiat. 120, 189.

Mock, J.E., PANero, C. \& Robinson, N. (1961) Marplan in the treatment of depression. A preliminary study. Dis. Nerv. Syst. 22, 320.

SJoQvisT, F. (1965) Interaction between monoamine oxidase inhibitors and other substances. R.S.M. Symposium No. 7: Clinical Effects of Interaction between drugs. Proc. Roy. Soc. Med. 58, 967.

Weiss, L.B. \& Pressman, M.D. (1961) A comparison of imipramine ('Tofranil') and amitriptyline ('Elavil') in the treatment of depression. Psychosomatics, 2, 293. 